\title{
The Effectiveness of Using MODIS Products for Monitoring Climate Change Risks over the Nile Delta, Egypt
}

\author{
Hossam Ismael \\ Geography and GIS Department, Faculty of Arts., Assiut University, New Valley Branch, Egypt
}

Email address:

hosam.ismael@artnv.au.edu.eg, hossam_geography@yahoo.com

To cite this article:

Hossam Ismael. The Effectiveness of Using MODIS Products for Monitoring Climate Change Risks over the Nile Delta, Egypt. International Journal of Environmental Monitoring and Analysis. Vol. 3, No. 6, 2015, pp. 382-396. doi: 10.11648/j.ijema.20150306.12

\begin{abstract}
Climate change is the one of greatest challenges that faces the human being nowadays as the Earth's climate is getting warmer. The National Oceanic and Atmospheric Administration (NOAA) and the National Aeronautics and Space Administration (NASA) have indicated that the temperature average of the Earth's surface has increased about 1.2 to $1.4 \mathrm{C}$ since 1900. Other climatic aspects are exposed to change as well such as patterns of precipitation and storms. The most common reason that leads to climate change is very likely human activities (e.g. fuel combustion and pollution). The Study area is the most affected region in the world by climate change impacts according to the fourth report of the Intergovernmental Panel on Climate Change ${ }^{4}$ th Report of IPCC, 2007. This report presents a scenario of destruction of the settlement centers in Nile Delta, Port Said in the east and Alexandria in the west (10 million people are at risk), besides, losing more than 86 square kilometers of the northern lakes, about 200,000 acres of the most valuable agricultural land as a result of high temperature and the consequent rise in average sea level. In Egypt, air pollutants (e.g. $\mathrm{SO}_{2}$ and $\mathrm{CO}_{2}$ ) gave rise to high concentrations of air pollutants especially in Nile delta, due to bio mass fire which is called 'Black Cloud' phenomenon. The main aim of this study was to present the effectiveness of using both the MODIS atmosphere data produced by the Terra mission and to describe differences with comparable products to be produced by Aqua. To achieve this aim the study used the HYDRA visualization software with the characteristics of the MODIS climatic data. Results obtained from MODIS data are validated by using the previously mentioned data sets to reveal the nature and the characteristics of the climate change. Fire, dust Detection with MODIS, AIRS, and AOD analysis clearly indicates large amounts of aerosols that form the black cloud events over various locations within the Nile delta region. Also the results agreed with the observed values in the study area, and highly required for many applications related to integrated remote sensing techniques with actual field measurements and data Meteorological Authority in different periods to reduce the risk of climate.
\end{abstract}

Keywords: HYDRA Visualization, Heat Island Impacts, MODIS Images, Terra and Aqua

\section{Introduction}

Rapid global climate change is induced by increased atmospheric greenhouse gas concentration, especially $\mathrm{CO}_{2}$, which results from human activities such as fossil fuel combustion and deforestation. This directly impacts terrestrial, which continues to change in both space and time (Melillo et al. 1993; Prentice et al. 2001; Nemani et al. 2003), and ultimately impacts in turn greatly affects the human society (Milesi et al. 2005). It has been shown that the oceans and the biosphere, especially terrestrial ecosystems, currently play a major role in reducing the rate of the atmospheric $\mathrm{CO}_{2}$ (Prentice et al. 2001; Schimel et al. 2001).

The Nile delta is suffering from high ambient concentrations of atmospheric pollutants including particulates (PM), carbon monoxide, nitrogen oxides, ozone and sulfur dioxide (Abu- Allaban et al., 2007, Abu-Allaban et al., 2002, El-Metwally et al., 2008). Pollution in this area is represented in what is called "Black cloud" over Nile delta. The existence of this black cloud could be attributed to many reasons among which are biomass burning, local emission and long rang of transport during the fall season. Several studies have been conducted to investigate this phenomenon using ground-based and satellite air quality data as compared to other megacities (Abu- Allaban et al., 2002, 2007, 2009; Alfaro and Wahab, 2006; El-Askary and Kafatos, 2008; El-Askary, 2006, 2008, 2010); El- Metwally et al., 2008; Favez et al., 2008; Kanakidou et al., 2011; Mahmoud et al., 
2008; and Marey et al., 2010; Prasad et al., 2010 and Zakey et al., 2004). Marey et al. (2010) have used a multi- sensor approach using the Moderate Resolution Imaging Spectrometer (MODIS) and the Multi-angle Imaging Spectro Radiometer (MISR) with meteorological data and trajectory analysis to examine the reasons for the black cloud formation over Cairo.

MODIS fire detection has identified the aerosol source which is burning the agricultural waste after harvest season in the Nile Delta region. Prasad et al. (2010) suggest that the long range of dust transport at high altitude $(2.5-6 \mathrm{~km})$ from the Western desert and its deposition over the Nile Delta region is one of the major contributors to air pollution episodes during this season. Nile delta and Great Cairo have witnessed different seasonal climate systems that are highly influenced by sand and dust storms coming from the western desert as well as local, increasing anthropogenic activities (El-Askary et al, 2010). As a result, it is characterized by a complicated meteorology that varies in the different times of the year. This study suggests that the pollution during the black cloud episode is the worst on human beings in addition to its effect on the local climate. During winter the climate is generally cold, humid and rainy; while during the summer season the weather is hot and dry (Zakey et al, 2008).

Several studies have been conducted to examine the main reasons for the increasing pollution levels in Cairo and Nile delta using ground-based and satellite air quality data (Zakey et al., 2004; Abu-Allaban et al., 2002, 2007; Alfaro and Wahab, 2006; El-Askary and Kafatos, 2008; Favez et al., 2008; Mahmoud et al., 2008; and El-Metwally et al., 2008; Marey et al., 2010 and Prasad et al., 2010). However, the genesis of the fall episodes (the black cloud season) is still under discussion and needs more investigations. In order to acquire further synoptic information and visualization of the aerosol and clouds characteristics, it is useful to analyze satellite data as well, since these data provide horizontal and vertical covering with fairly high (e.g. daily and monthly) temporal resolution. (Marey et al, 2010, 2011) utilized data from several satellite instruments to examine the most likely reasons for the black cloud formation over Nile delta.

In addition to the above, several studies have proved that the general behavior of MODIS retrieved aerosol optical depth (t) and has been validated against ground-based measurements, and good agreements were reported between MODIS and Sun photometer (SP) t over both oceans and land regions [e.g., Remer et al., 2002, 2005]. Reported in these studies, the $t$ retrieved from MODIS and SP share a high degree of correlation, and the uncertainty of MODIS t over oceans was estimated to be $0.03 \pm 0.05$ t [e.g., Remer et al., 2002, 2005]. On other hand (Jianglong Zhang and Jeffrey S. Reid, 2006) found fairly similar results using 1 years' worth of Terra (MOD04) and AQUA (MYD04) MODIS level II over-ocean aerosol product.

The impacts of pollution on aerosol optical properties and the long range of dust transport have been widely studied over Asia and other regions. Recent studies, using different sensors over optical and microwave spectra, have analyzed aerosol optical properties during dust and pollution events over Northern India and East Asia (Uno et al. 2001, Carmichael et al. 2002, Di Girolamo et al. 2004, Singh et al. 2004, El-Askary et al. 2006).

Dust storms have also been widely investigated over Egypt through a multisensory approach utilizing the differing dust behaviour over ultraviolet, visible and microwave regions of the spectrum (El-Askary et al. 2003), as well as Saharan dust transportation (Kallos et al. 2006). However, a lot still needs to be done for Africa and especially for North Africa, where one of the highest populated cities of the world is present. El-Askary (2006) has recently presented a detailed seasonal analysis of the aerosol parameters over Cairo and the Greater Delta region from 2000 to 2005 . High AOD values were found over Cairo and the Greater Delta region during the spring and autumn times of the year using MODIS data. These times represent the periods of dust storms occurrence (April and May) and, more recently, the occurrence of black cloud (September and October).

Also, El-Askary et al (2008) have found that, since 1999, a black cloud appeared, above the Nile Delta and Cairo, during October and was reported by the media. During that time of the year, farmers have burned rice straw, a by-product from the rice harvest, to clear fields for the next crop. The main aim of this study id to present the effectiveness of using each of the MODIS atmosphere data products, that are being produced by the Terra mission and to describe differences with comparable products produced by Aqua. To achieve these objectives, the study has applied some threshold tests, such as MODIS fire detection, investigating Aerosols with MODIS, and dust detection with MODIS and AIRS.

\section{Study Area}

The Nile delta covers only $2 \%$ of Egypt's area but hosts $47 \%$ of the country's population and comprises $65 \%$ of its agricultural land. According to (Hereher, 2009), the Nile Delta was formed during flood seasons by Nile sediments. After passing Cairo, the Nile bifurcates into two branches: Rosetta in the west and Damietta in the east. Between and beyond these two promontories a wide coastal plain exists that was built up during the last 8-6 ka (Stanley and Warne 1994), forming one of the most famous deltas in the world in earlier times there were seven branches each one has its own lobe into the Mediterranean Sea. Five of them have silted up, leaving only the Rosetta and Damietta tributaries (Sneh and Weissbrod 1973).

The Nile Delta occupies an area of $22,000 \mathrm{~km}^{2}$, and generally flat; its apex at Cairo (160 km upstream) lies at an elevation of $+18 \mathrm{~m}$ (Sestini 1992). The climate in the Nile Delta is Mediterranean: hot in the summer and mild in the winter. Temperature averages are $19^{\circ} \mathrm{C}$ in the winter and $33^{\circ} \mathrm{C}$ in the summer. Precipitation ranges from $200 \mathrm{~mm} /$ year along the Mediterranean coast to only $22 \mathrm{~mm} /$ year at Cairo. Excluding Great Cairo, the Nile Delta contains another 10 administrative governorates: Alexandria, Kafr El-Sheikh, El-Dakahlia, Damietta, Port Said, El-Behira, El-Gharbia, 
El-Minofia, El-Sharkia, and Ismailia. Government statistics (the Central Agency for Public Mobilization and Statistics, http://www.capmas.gov.eg/) report that these governorates host $47 \%$ of Egypt's 88 million populations in the 2015 census. The delta coast possesses many highly populated cities, such as Alexandria, Damietta, Port Said, and Rosetta. Delta coast is characterized by its urban, industrial, touristic and international trading importance, In addition, the region contains $63 \%$ of Egypt's agricultural land which constitutes 8.6 million acres in 2005 (Hereher, 2009), and $25 \%$ of the total Mediterranean coastal wetlands, that are not only a fishing resource but also a good shelter for migratory birds (Sestini 1992).

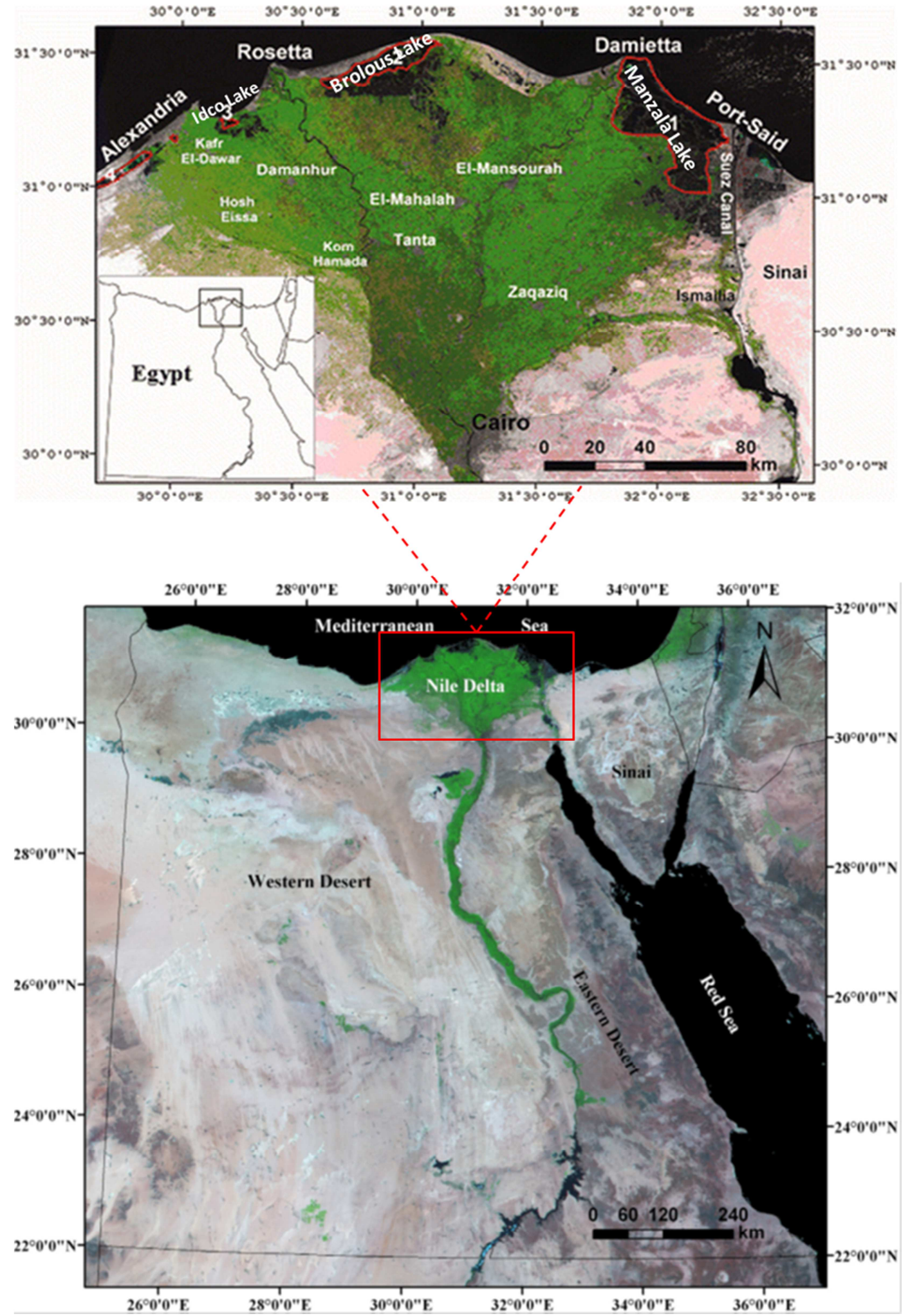

Figure 1. An image of the Nile delta on $12^{\text {th }}$ march 2013 compiled from 4 MODIS tiles. 


\section{MODIS and Its Products}

The MODerate-resolution Imaging Spectroradiometer (MODIS) is one of five scientific instruments onboard the satellite platform, Terra, part of NASA's Earth Observation System (EOS), It provides data for retrieving land surface temperature (LST) at $1-\mathrm{km}$ resolution with almost daily coverage of the Earth, which is invaluable for both local and global change research. The Moderate Resolution Imaging Spectroradiometer (MODIS) is an Earth Observing System (EOS) and a facilitating instrument that is currently flying aboard the Terra and Aqua spacecraft. It suits the global monitoring of atmospheric properties from space, and is based on heritage sensors such as the Advanced Very High Resolution Radiometer (AVHRR), Landsat Thematic Mapper (TM), High-resolution Infrared Radiation Sounder (HIRS), and the Nimbus-7 Coastal Zone Color Scanner (CZCS). The wide spectral range $(0.41-14.24 \mathrm{~m})$, frequent global coverage (one to two days revisit), and two high spatial resolution bands $(250 \mathrm{~m})$, permit state of the art global monitoring of atmospheric profiles, column water vapor amount, aerosol particles, and the subsequently formed clouds (King et al, 1999). MODIS scans a swath width of $2330 \mathrm{~km}$ that is sufficiently wide to provide nearly complete global coverage every two days from a polar-orbiting, sun-synchronous, platform at an altitude of $705 \mathrm{~km}$. MODIS provides images in 36 spectral bands between 0.415 and $14.235 \mathrm{~m}$ with spatial resolutions of $250 \mathrm{~m}$ (two bands), $500 \mathrm{~m}$ (five bands), and $1000 \mathrm{~m}$ (29 bands) (King et al 2003).

MODIS twin sensors were launched under the auspices of the NASA Earth Observing System (EOS) program: the first on 18 December 1999 aboard the Terra satellite, and the second on 4 May 2002 aboard the Aqua satellite; and both have measured the reflected and emitted radiance from the Earth and the atmosphere, day and night. Terra and Aqua, which are both polar-orbiting satellites, cross the equator during the daytime at approximately 1030 (morning) and 1330 (afternoon) local time (LT), respectively. Radiance data are acquired by MODIS in 36 spectral bands, spanning $0.645-$ $14,385 \mu \mathrm{m}$ four focal plane assemblies (Table.1), wavelengths, which range from the visible (VIS) through the near-infrared (NIR) and mid-infrared (MIR) up to the thermal infrared (TIR) regions of the electromagnetic spectrum. They are acquired in one of three spatial resolutions at nadir: $0.25 \mathrm{~km}$ (bands $1-2$ : VIS), $0.5 \mathrm{~km}$ (bands 3-7: VIS-MIR), and $1 \mathrm{~km}$ (bands 8- 36: VIS-TIR) (King et al, 1992).

Table 1. MODIS Channel Number, Wavelength (m), and Primary Application. From (Manzel, 2009).

\begin{tabular}{|c|c|c|c|c|c|}
\hline \multicolumn{3}{|c|}{ MODIS Reflected Solar Bands } & \multicolumn{3}{|c|}{ MODIS Thermal Emissive Bands } \\
\hline Band & Wavelength (micron) & Primary application & Band & Wavelength (micron) & Primary application \\
\hline 1,2 & $0.645,0.866$ & Land, Clouds & $20-23$ & $3.75(2), 3.95,4.05$ & Surface / cloud temperature \\
\hline 3,4 & $0.470,0.555$ & Land, Clouds & 24,25 & $4.46,4.51$ & Atmospheric temperature \\
\hline $5-7$ & $1.24,1.64,2.13$ & Land, Clouds & 27,28 & $6.71,7.32$ & Water vapor \\
\hline $8-10$ & $0.415,0.443,0.490$ & Ocean color & 29 & 8.55 & Surface / cloud temperature \\
\hline $11-13$ & $0.531,0.565,0.653$ & Ocean color & 30 & 9.73 & Ozone \\
\hline $14-16$ & $0.681,0.750,0.865$ & Ocean color & 31,32 & $11.03,12.02$ & Surface / cloud temperature \\
\hline $17-19$ & $0.905,0.936,0.940$ & Water vapor & 33,34 & $13.33,13.63$ & Cloud top properties \\
\hline 26 & 1.375 & Cirrus clouds & 35,36 & $13.93,14.23$ & Cloud top properties \\
\hline
\end{tabular}

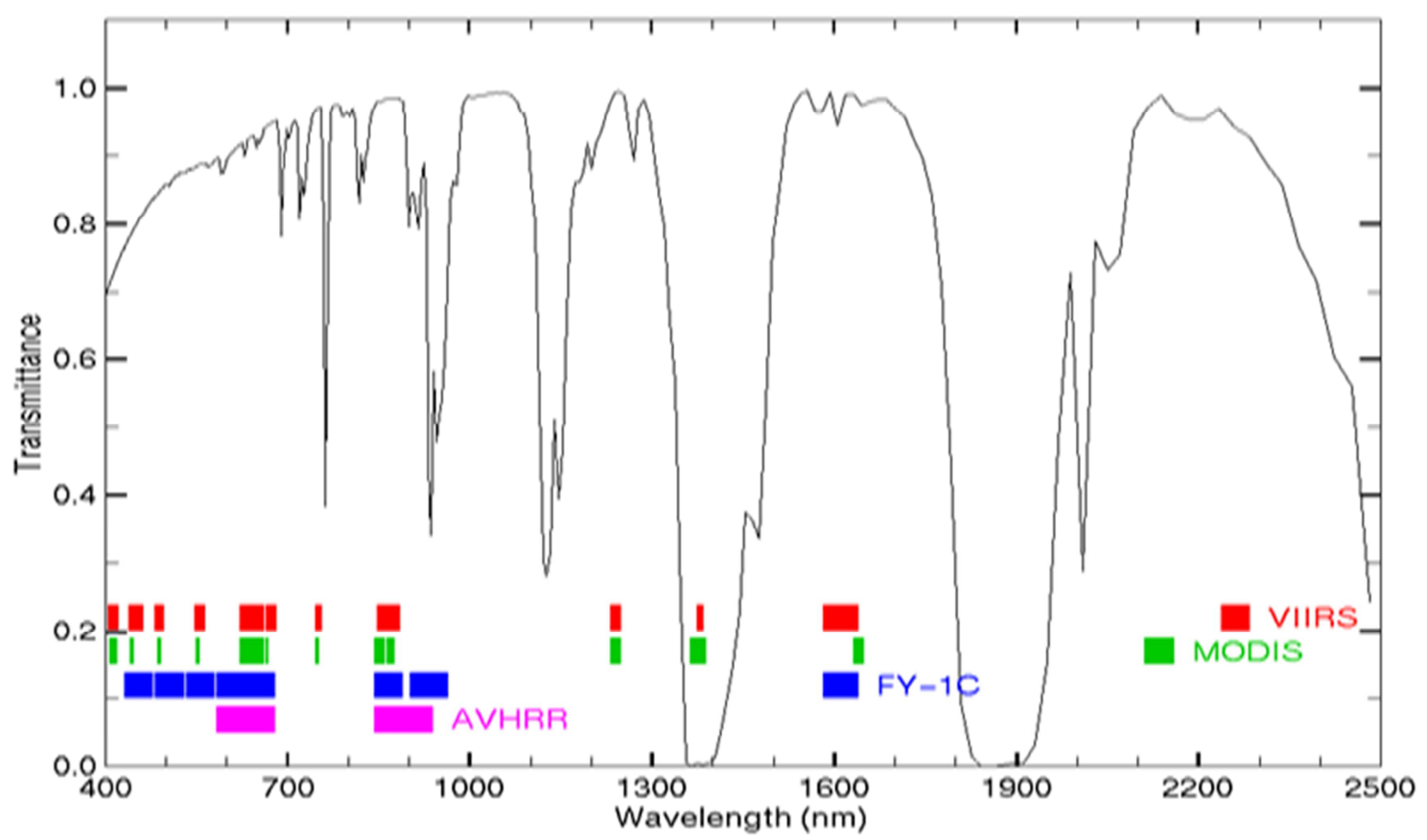




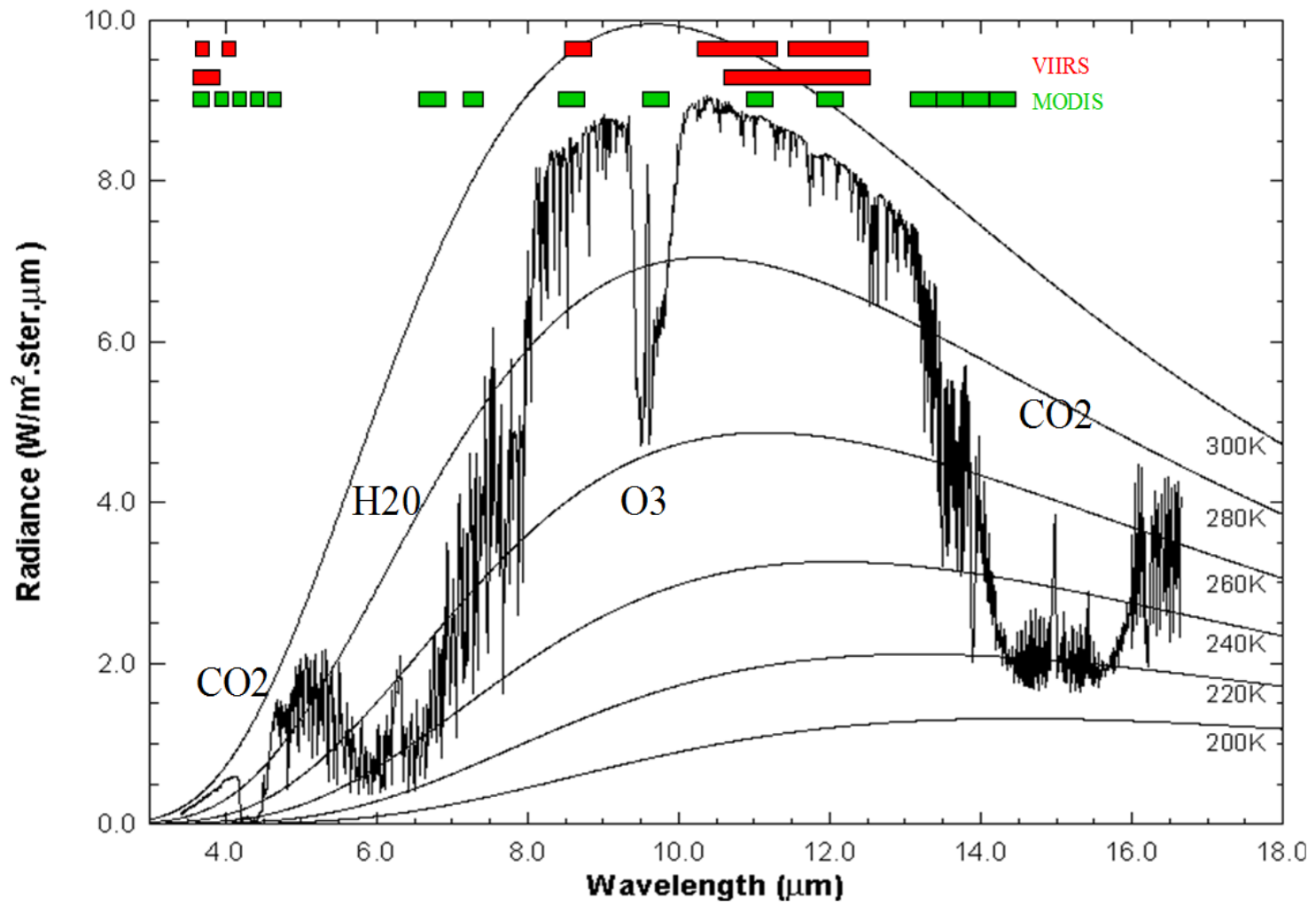

Figure 2. Visible and Infrared absorption features and MODIS spectral band locations (Manzel et al, 2006).

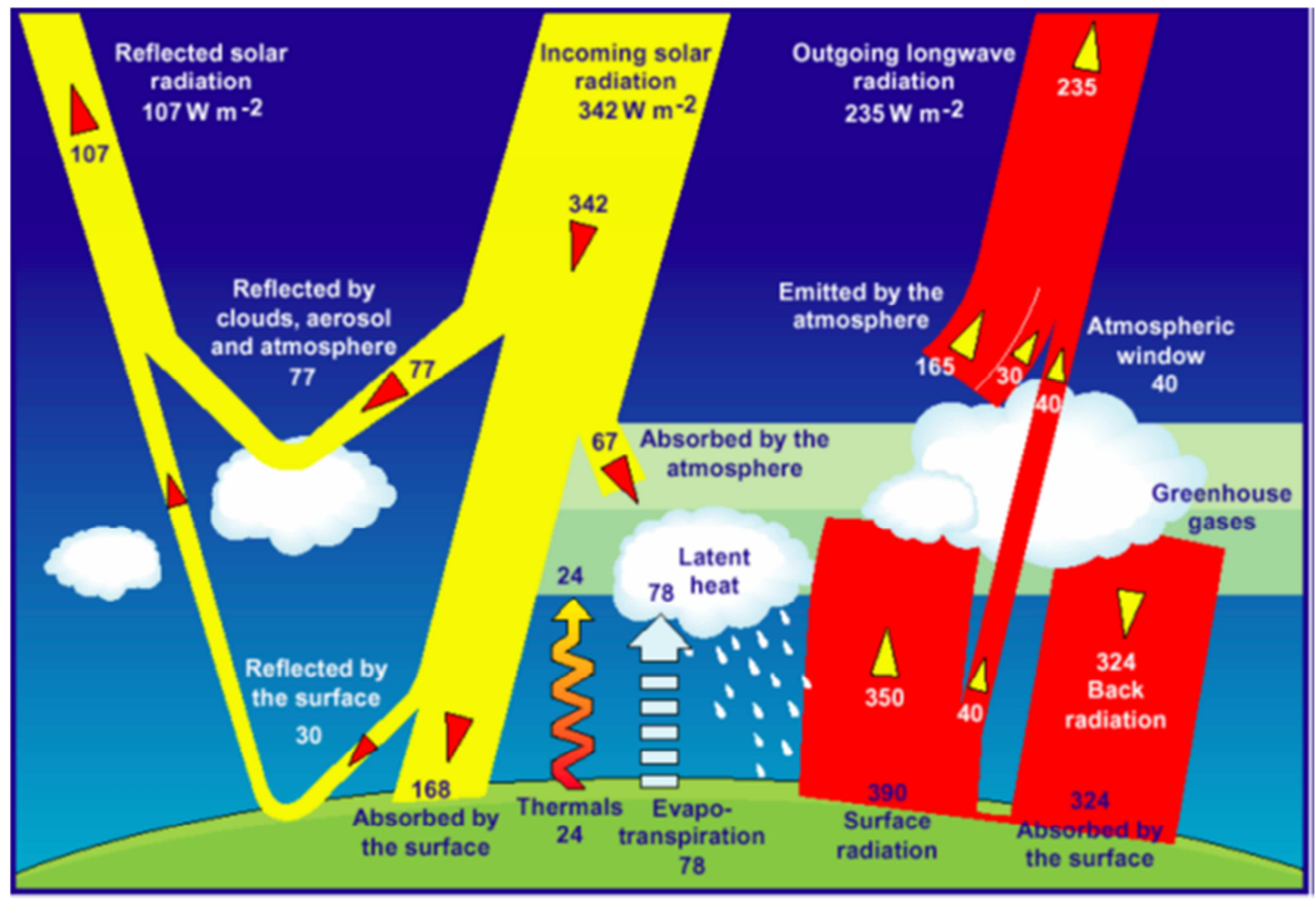

Figure 3. Climate system energy balance with role of clouds, evaporation, and other radiative processes indicated in watt per meters squared (Parkinson and Greenstone, 2000). 
The products generated from are archived continuously by appropriate NASA data centers and are distributed freely. The algorithms used to generate these products undergo periodic revisions, and the data users are not always sure about the version and quality of the products they are using at any given time. It is, therefore, necessary to conduct periodic calibration and evaluation of the products to keep track of their evolution and make the information available to users (Antonili et al, 2008). (Figure.2) shows MODIS emissive bands superimposed on high resolution earth atmosphere emission spectra with Planck function curves at various temperatures superimposed (top) and MODIS reflective spectral bands superimposed on the earth reflection spectra (bottom). (Figure.3) illustrates the annual mean of global energy balance for the earth-atmosphere system. Tracking the global energy balance trends is a vital part of climate change research.

The MODIS spectral bands have been chosen to be sensitive to various reflection, absorption, and scattering spectral signatures. (Figure.4) shows the processing schema used for deriving atmospheric products from level 0 (raw instrument data) to level 1 (calibrated earth located radiances) to level 2 ( $5 \times 5$ field of view derived atmospheric products) to level 3 (time composited global product fields in even interval lat-lon grid boxes).

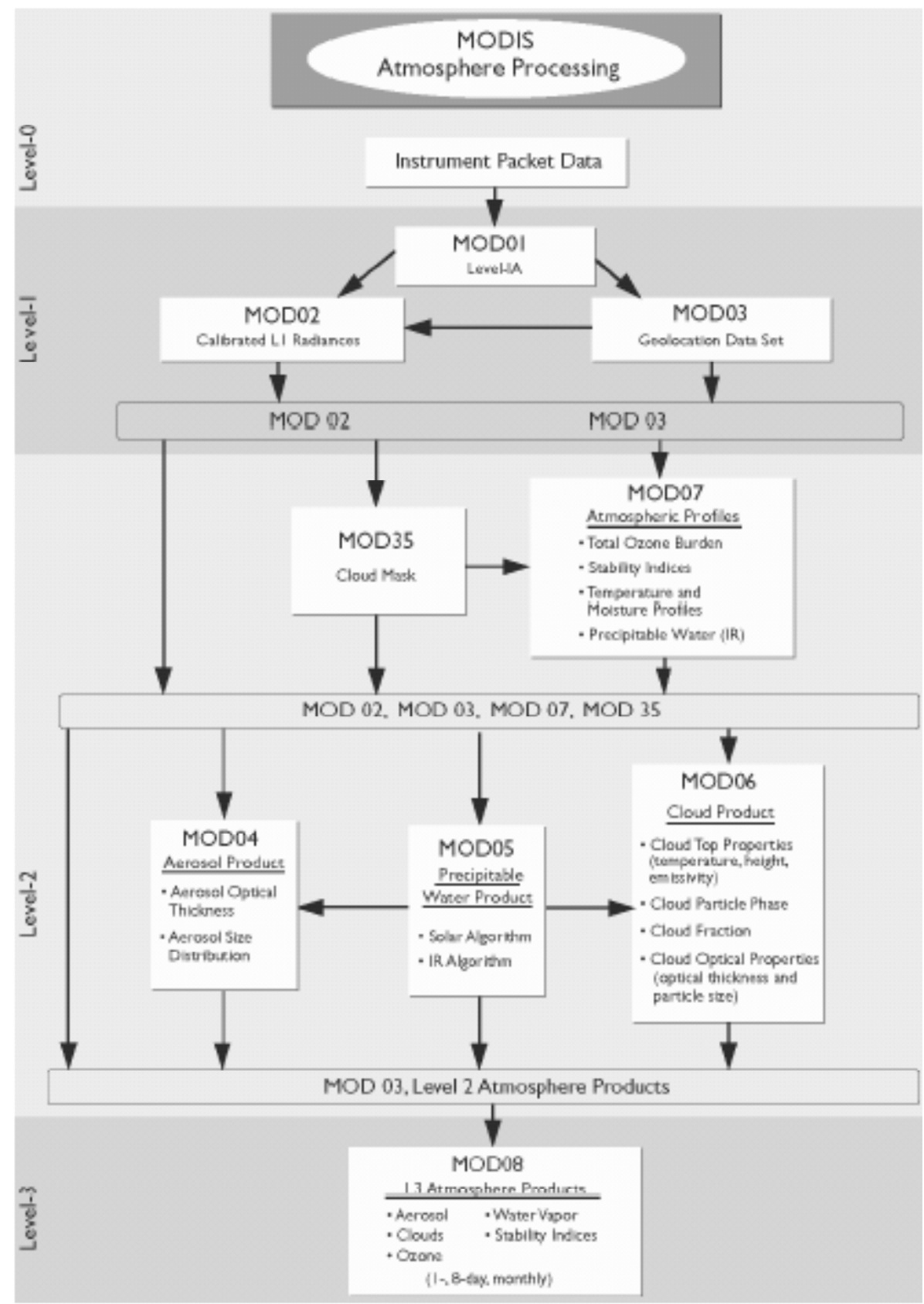

Figure 4. MODIS Atmospheric Processing schema from level 0 (raw instrument data) to level 1 (calibrated earth located radiances) to level 2 (5x5 field of view derived atmospheric products) to level 3 (time composited global product fields in even interval lat-lon grid boxes) adapted from the EOS Data Products Handbook. 
The products generated from MODIS are archived continuously by appropriate NASA data centers and are distributed freely. The algorithms used to generate these products undergo periodic revisions, and data users are not always sure about the version and quality of the products they are using at any given time. Therefore, it is necessary to conduct periodic calibration and evaluation of the products to keep track of their evolution and make the information available to users.

The MODIS spatial resolution is $250-\mathrm{m}$ bands are centered at 0.65 and $0.86 \mu \mathrm{m}$ with the $500-\mathrm{m}$ bands at $0.47,0.56,1.24$, 1.63 , and $2.13 \mu \mathrm{m}$. Each band's spectral response is determined by an interference filter overlying a detector array imaging a 10-km along-track scene for each scan (i.e., 40, 20, and 10 element arrays for the 250,500, and 1000-m bands, respectively. The MODIS-derived aerosol properties $(\mathrm{t})$ and the fraction of fine mode particle over land [Kaufman et al., 1997a; Chu et al., 1998, 2002] in tandem with those (t), the fraction of fine mode particle, and effective radius) over ocean [Tanre' et al., 1997, 1999; Remer et al., 2002,2005] enable to study the global aerosols comprehensively.

\section{Materials and Methods}

The study is based on MODIS fire algorithm and uses a series of tests to determine if a pixel contains a fire in order to measure the impacts of the black cloud over Nile delta (table.2). It has also used the visible thresholds tests and spectral cloud mask (MOD35) which serves as a primary ancillary input to the other cloud algorithms.

The focus of the product is to prove whether the pixel is unobstructed between the surface and satellite or not. In addition to the potentiality for obstruction in the line of sight due to clouds, heavy aerosols (e.g., fire and dust detection) and will act also to decrease the likelihood of finding clear-sky conditions. The data of this study are collected during two years of monthly average observations of AOD over the Delta region derived from MODIS level-2 AOT atmospheric daily products data at a $10 \mathrm{~km}$ resolution.

Finally, the study is based on HYDRA. HYper-spectral data viewer for Development of Research Applications. HYDRA enables interrogation of multispectral (including hyperspectral) fields of data so that (a) pixel location and spectral measurement values (radiance or brightness temperature) can be easily displayed; (b) spectral channels can be combined in linear functions and the resulting images are displayed; (c) false color images can be constructed from multiple channel combinations; (d) scatter plots of spectral channel combinations can be viewed; (e) pixels in images can be found in scatter plots and vice versa; (f) transects of measurements are displayed, and (g) temperature and moisture as well as spectra from selected pixels are compared. HYDRA software has become a part of the World Meteorological Organization Virtual Laboratory for Satellite Meteorology.

Table 2. Summary of some MODIS Cloud Tests.

\begin{tabular}{|c|c|c|c|}
\hline Scene & Solar/Reflectance & Thermal & Comments \\
\hline $\begin{array}{l}\text { Low cloud } \\
\text { over water }\end{array}$ & $\begin{array}{l}\mathrm{R}_{0.86}, \mathrm{R}_{0.67} / \mathrm{R}_{0.86} \\
\mathrm{BT}_{11}-\mathrm{BT}_{3.7}\end{array}$ & $\begin{array}{l}\text { Difficult, } \\
\text { Compare } \mathrm{BT}_{11} \text { to daytime mean clear-sky values of } \mathrm{BT}_{11} \text {; } \\
\mathrm{BT}_{11} \text { in combination with } \mathrm{BT} \text { difference tests; } \\
\text { Over oceans, expect a relationship between } \\
{\left[\mathrm{BT}_{11}-\mathrm{BT}_{8.6}\right],\left[\mathrm{BT}_{11}-\mathrm{BT}_{12}\right] \text { due to water vapor correlation }} \\
\text { to SST }\end{array}$ & $\begin{array}{l}\text { Spatial and temporal uniformity tests sometimes } \\
\text { used over water scenes; } \\
\text { Beware of Sun-glint regions }\end{array}$ \\
\hline $\begin{array}{l}\text { High Thick } \\
\text { cloud over } \\
\text { water }\end{array}$ & $\mathrm{R}_{1.38}, \mathrm{R}_{0.86}, \mathrm{R}_{0.67} / \mathrm{R}_{0.86}$ & $\begin{array}{l}\mathrm{BT}_{11 ;} \mathrm{BT}_{13.6} ; \mathrm{BT}_{6.7} \\
{\left[\mathrm{BT}_{11}-\mathrm{BT}_{8.6}\right]} \\
{\left[\mathrm{BT}_{11}-\mathrm{BT}_{12}\right]}\end{array}$ & Easy, good contrast in vis and IR \\
\hline $\begin{array}{l}\text { High Thin } \\
\text { cloud over } \\
\text { water }\end{array}$ & $\begin{array}{l}\mathrm{R}_{1.38}, \Delta \mathrm{R}_{0.86} \\
{\left[\mathrm{R}_{0.65}-\mathrm{R}_{1.6}\right] /\left[\mathrm{R}_{0.65}+\mathrm{R}_{1.6}\right]}\end{array}$ & $\begin{array}{l}\mathrm{BT}_{6.7} ; \mathrm{BT}_{13.9} \\
{\left[\mathrm{BT}_{11}-\mathrm{BT}_{12}\right]} \\
{\left[\mathrm{BT}_{3.7}-\mathrm{BT}_{12}\right]} \\
{\left[\mathrm{BT}_{8.6}-\mathrm{BT}_{11}\right]}\end{array}$ & $\begin{array}{l}\text { For } \mathrm{R}_{1.38} \text {, be careful of surface reflectance for } \\
\text { atmospheres with low total water vapor amounts. } \\
\text { For BT difference tests, beware of variations in } \\
\text { surface emissivity. }\end{array}$ \\
\hline $\begin{array}{l}\text { Low cloud } \\
\text { over } \\
\text { vegetation }\end{array}$ & $\begin{array}{l}\mathrm{R}_{0.86}, \mathrm{R}_{0.67} / \mathrm{R}_{0.87} \\
\mathrm{BT}_{11}-\mathrm{BT}_{3.7} \\
{\left[\mathrm{R}_{0.86}-\mathrm{R}_{0.65}\right]} \\
/\left[\mathrm{R}_{0.86}+\mathrm{R}_{0.65}\right]\end{array}$ & Difficult, $\mathrm{BT}_{11}$ in combination with $\mathrm{BT}$ difference tests. & $\begin{array}{l}\text { NDVI (Normalized Difference Vegetation Index). } \\
\text { Other ratio tests also are good. Can make tests a } \\
\text { function of ecosystem. }\end{array}$ \\
\hline $\begin{array}{l}\text { High Thick } \\
\text { cloud over } \\
\text { vegetation }\end{array}$ & $\begin{array}{l}\mathrm{R}_{1.38}, \mathrm{R}_{0.86}, \mathrm{R}_{0.67} / \mathrm{R}_{0.86} \\
{\left[\mathrm{R}_{0.86}-\mathrm{R}_{0.65}\right]} \\
/\left[\mathrm{R}_{0.86}+\mathrm{R}_{0.65}\right]\end{array}$ & $\begin{array}{l}\mathrm{BT}_{11} ; \mathrm{BT}_{13.9} ; \mathrm{BT}_{6.7} \\
{\left[\mathrm{BT}_{11}-\mathrm{BT}_{8.6}\right]} \\
{\left[\mathrm{BT}_{11}-\mathrm{BT}_{12}\right]}\end{array}$ & $\begin{array}{l}\text { Can make tests a function of ecosystem to account } \\
\text { for variations in surface emittance and reflectance. }\end{array}$ \\
\hline $\begin{array}{l}\text { High Thin } \\
\text { cloud over } \\
\text { vegetation }\end{array}$ & $\begin{array}{l}\mathrm{R}_{1.38}, \mathrm{R}_{0.86}, \mathrm{R}_{0.67} / \mathrm{R}_{0.86} \\
{\left[\mathrm{R}_{0.86}-\mathrm{R}_{0.65}\right]} \\
/\left[\mathrm{R}_{0.86}+\mathrm{R}_{0.65}\right]\end{array}$ & $\begin{array}{l}\mathrm{BT}_{13.9} ; \mathrm{BT}_{6.7} \\
{\left[\mathrm{BT}_{11}-\mathrm{BT}_{8.6}\right]} \\
{\left[\mathrm{BT}_{11}-\mathrm{BT}_{12}\right]}\end{array}$ & $\begin{array}{l}\text { Beware of variations in surface emittance and } \\
\text { reflectance. }\end{array}$ \\
\hline $\begin{array}{l}\text { Low cloud } \\
\text { over bare } \\
\text { soil }\end{array}$ & $\begin{array}{l}\mathrm{R}_{0.86}, \mathrm{R}_{0.67} / \mathrm{R}_{0.86} \\
{\left[\mathrm{BT}_{11}-\mathrm{BT}_{3.7}\right]}\end{array}$ & $\begin{array}{l}\mathrm{BT}_{11} \text { in combination with brightness temperature } \\
\text { difference tests. } \\
{\left[\mathrm{BT}_{3.7}-\mathrm{BT}_{3.9}\right]}\end{array}$ & $\begin{array}{l}\text { Difficult due to brightness and spectral variation in } \\
\text { surface emissivity. Surface reflectance at } 3.7 \text { and } 3.9 \\
\mu \mathrm{m} \text { is similar. }\end{array}$ \\
\hline
\end{tabular}

MODIS data are stored in the Hierarchical Data Format (HDF) (cf ,.hdf.ncsa.uiuc.edu .(Within this HDF file, each product has an associated Science Data Set (SDS) name. For example, the cloud-top pressure product is given the SDS
name“Cloud_Top_Pressure ,"and for Terra is stored in the HDF data designation file "MOD_06L) "2which contains all Level 2-cloud-top property and optical/microphysical retrieval SDS's). Similarly, cloud mask results are found in the 
"MOD_35L"2HDF file.

\section{The Results}

MODIS fire algorithm is used to differentiate fire pixels from nearby non-fire (background) pixels. It is used as an indicator for the black cloud impacts. This involves comparing the potential fire pixel to the surrounding pixels. This contextual approach uses the average brightness temperature of the non-fire pixels in Band 21(3.99 m) that surround the potential fire pixel and also the Mean Absolute Deviation (MAD). MAD is the mean of the absolute value of the differences between the average and the deviation from the average.
MODIS fire algorithm has used to differentiate fire pixels from nearby non-fire (background) pixels. It was used as an indicator for the black cloud impacts. This involves comparing the potential fire pixel to the surrounding pixels. This contextual approach uses the average brightness temperature of the non-fire pixels in Band 21(3.99 $\mu \mathrm{m})$ that surround the potential fire pixel and also the Mean Absolute Deviation (MAD). MAD is the mean of the absolute value of the differences between the average and the deviation from the average:

$\mathrm{MAD}=\frac{1}{\boldsymbol{N}} \sum_{i}\left|\boldsymbol{x}_{i}-\overline{\boldsymbol{x}}\right|$ where $\mathrm{i}$ is the number of points you are summing.
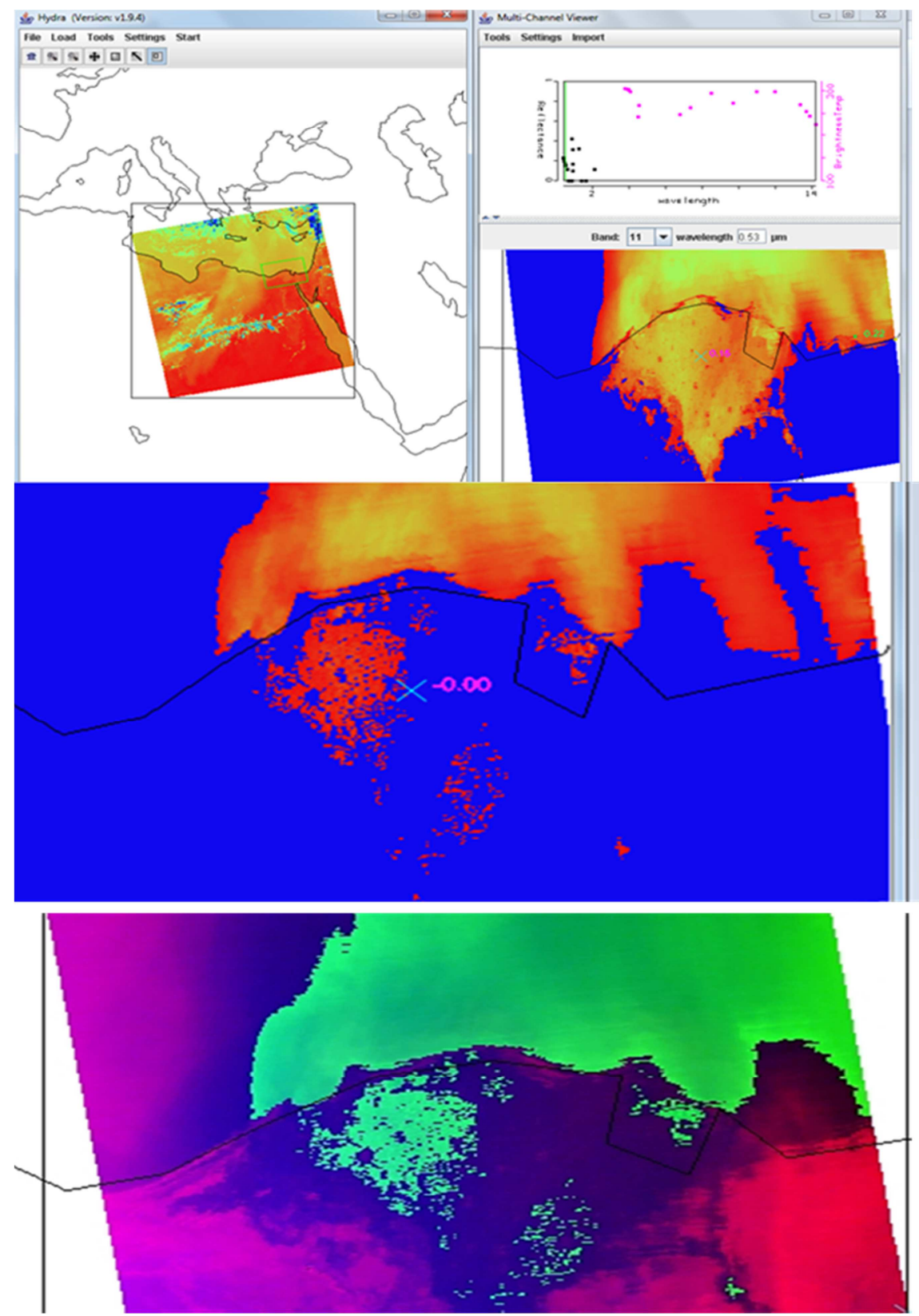

Figure 5. Black cloud display with $11 \mu \mathrm{m}$ brightness temperature image at $10 \mathrm{~km}$ from Aqua MODIS on 22 March 2010 at 1110 UTC (top), $1 \mathrm{~km}$ resolution Band $3(0.47 \mu \mathrm{m})$, Band 13io $(0.67 \mu \mathrm{m})$ reflectance image in the Multi-Channel Viewer (middle and down) respectively. 
For pixels that did not pass the first BT4 test, they must pass the next 3 dynamic thresholds to be labeled a fire pixel (Figure 5).

\begin{tabular}{ll}
\hline Threshold tests & $\begin{array}{l}\text { Thresholds for data selected in } \\
\text { (Figure. 5) }\end{array}$ \\
\hline BTDIF4-11 $>$ Average & BTDIF4-11 $>3.2 \mathrm{~K}+3.5 *(.63) \mathrm{K}$ \\
BTDIF4-11 + 3.5 (MAD & BTDIF4-11 $>5.40$ \\
BTDIF4-11) & BTDIF4-11 $>6 \mathrm{~K}+3.2 \mathrm{~K}$ \\
BTDIF4-11 $>$ Average & BTDIF4-11 $>9.2 \mathrm{~K}$ \\
BTDIF4-11 + 6 K & BT4 $>298.52 \mathrm{~K}+3 * 16.57 \mathrm{~K}$ \\
BT4 (Band 21 3.99 $\mu \mathrm{m} \mathrm{BT)}>$ & BT4 $>348.23 \mathrm{~K}$ \\
Average BT4 + 3(MAD BT4) & \\
\hline
\end{tabular}

Manzel et al (2009) have concluded that the high reflectance measurements result from thick clouds at all levels, and the infrared window brightness temperature provides a good indication of the cloud level. Intermediate reflectance data are subject to ambiguous interpretations since they result from a mixture of cloud and surface contributions. Visible data used in the determination of the cloud mask must be uncontaminated by sun glint. Algorithms which include solar reflectance data are constrained to solar zenith angles less than $85^{\circ}$. Sun glint occurs when the reflected sun angle, $\theta \mathrm{r}$, lies between $0^{\circ}$ and approximately $36^{\circ}$.

$$
\cos \theta r=\sin \theta \sin \theta o \cos \varphi+\cos \theta \cos \theta o
$$

Where $\theta 0$ is the solar zenith angle, $\theta$ is the viewing zenith angle, and $\varphi$ is the azimuthal angle. Sun glint is also a function of surface wind and sea state. The entire single pixel tests mentioned so far relies on thresholds. Thresholds are never global. There are always exceptions and the thresholds must be interpreted carefully.

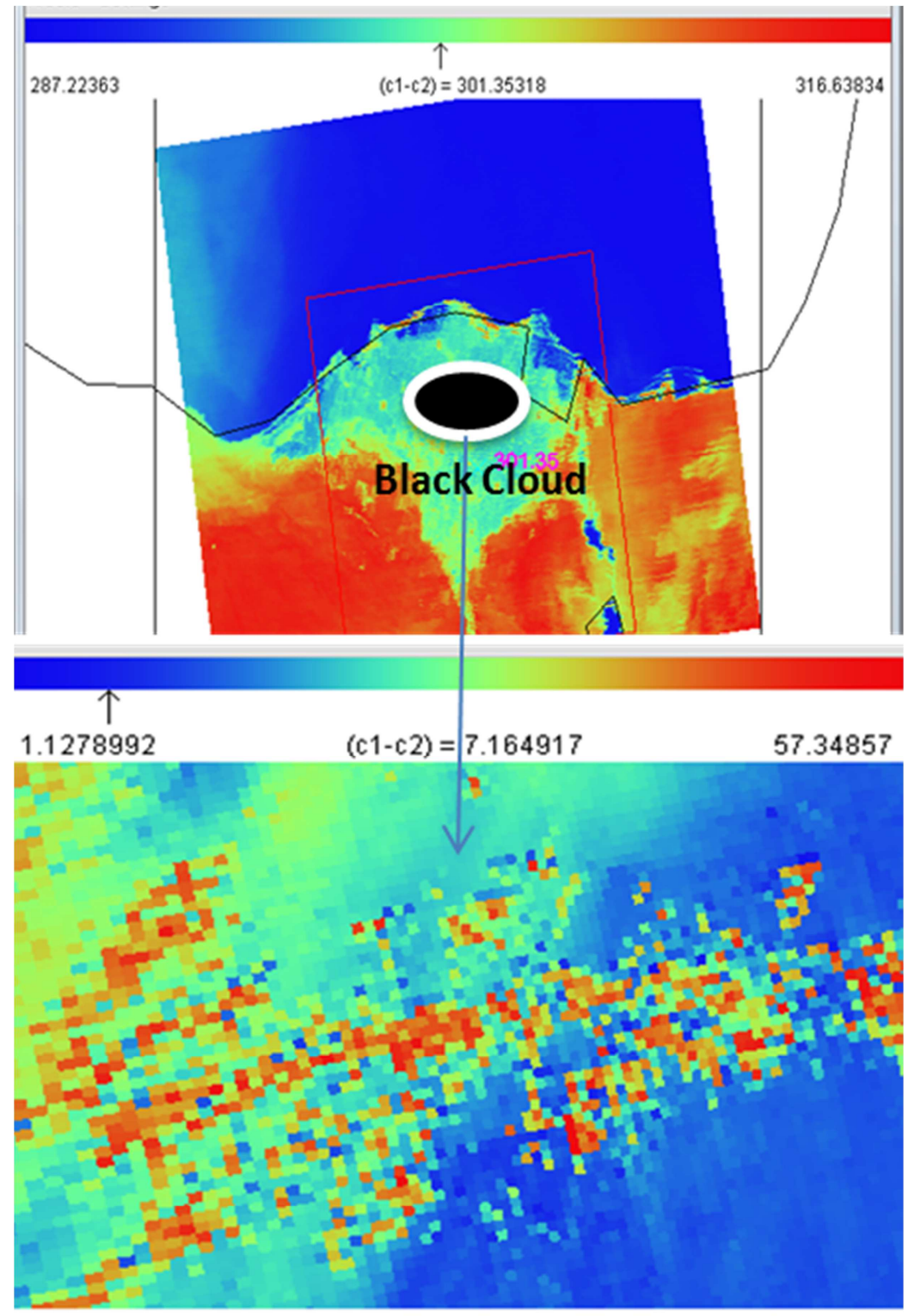

c1:20, c2:31

Figure 6. The potential fire of black cloud over Nile delta region a BT4 average and BT4 MAD and a BTDIF4-11 average and BTDIF4-11 MAD, showing biomass fir occurrence at lower altitudes. $900 \mathrm{mb}$. 
By loading Band $22(3.99 \mu \mathrm{m})$ into the Multi-Channel Viewer and overlay the MODIS fire Level 2 product. The fire product has displayed over the image and a new MODIS Fire Mask Product window will be displayed, with a button at the bottom that allows you to toggle the mask. After that, we compute and select a potential fire of black cloud over Nile delta region and determine a BT4 average and BT4 MAD and a BTDIF4-11 average and BTDIF4-11 MAD (figure.6).

By loading Band $22(3.99 \mathrm{~m})$ into the Multi-Channel Viewer and overlay the MODIS fire Level 2 product. The fire product is displayed over the image and a new MODIS Fire Mask Product window will be displayed, with a button at the bottom that allows toggling the mask. After that, we compute and select a potential fire of black cloud over Nile delta region and determine a BT4 average and BT4 MAD and a BTDIF4-11 average and BTDIF4-11 MAD (figure.6).

The black cloud over Nile delta was detected with threshold tests that rely on brightness temperatures in three infrared spectral bands; they are BT11, BT13.9, and BT6.7. Infrared window thresholds, BT11, are practical in certain conditions; however, they will vary in moisture content of the atmosphere. Over land, BT11 is further complicated by the fact that the surface emissivity varies appreciably according to soil and vegetation type. Thus, BT11 is used primarily to detect high, thick clouds and thresholds are set accordingly.

In addition, black clouds are likely present when BT11 is less than $300 \mathrm{~K}$ over Nile delta. BT13.9 provides good sensitivity to the relatively semi-arid regions of the atmosphere because of $\mathrm{CO} 2$ absorption. The same is true for BT6.7 because of $\mathrm{H}_{2} \mathrm{O}$ absorption. These spectral bands receive most of their radiation near $300 \mathrm{hPa}$ and only clouds above $500 \mathrm{hPa}$ make strong radiance contributions; negligible contributions come from the earth surface. Thus a threshold for BT13.9 and BT6.7 can isolate clouds above $500 \mathrm{hPa}$ (Figure.6).

According to dust detection affecting Nile delta with MODIS and AIRS, it was illustrated that by using the main menu

load MOD021KM.A2008055.1130.005.2014056124414.hdf. This granule shows a dust storm over Egypt. The temperature brightness differences show a larger range over Nile delta by representing the Band $31(11 \mathrm{~m})$ on the $\mathrm{x}$-axis and [Band 29 $(8.6 \mathrm{~m})$ minus Band $31(11 \mathrm{~m})]$ on the $y$-axis. In addition to the capability of distinguishing dust storm from clouds using these channels (Figure.7)

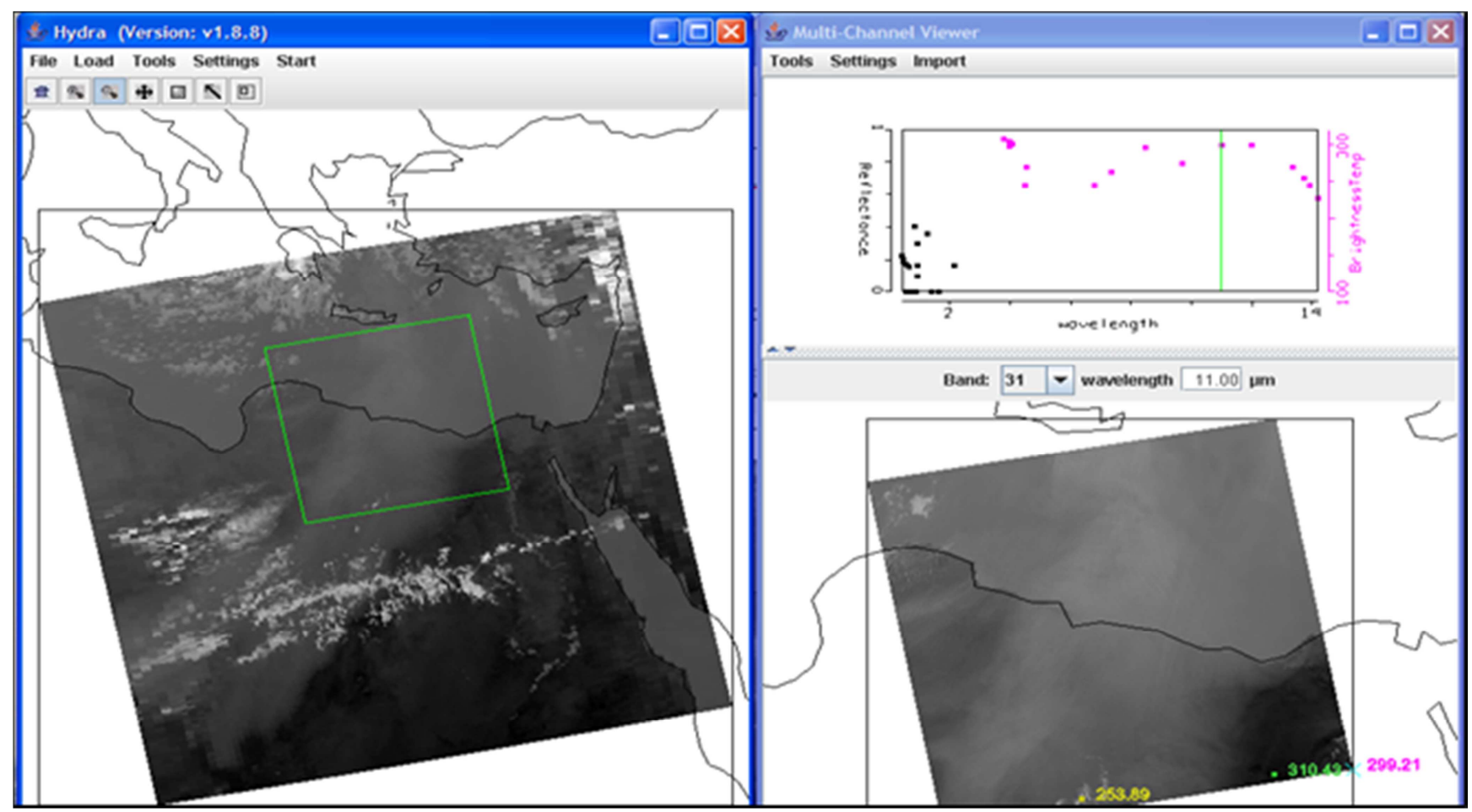

Figure 7. Dust storm scene over Egypt affecting Nile delta viewed by MODIS

The MODIS aerosol product is used to study aerosol climatology, sources and sinks of specific aerosol types (e.g., biomass burning aerosol or black cloud over Nile delta), interaction of aerosols with clouds, the hydrological cycle and atmospheric dynamics, and atmospheric corrections of remotely sensed surface reflectance over the land (Figure. 8). MODIS measures aerosols, which include dust, sea salt, smoke from agriculture fires, and some kinds of pollution, directly affect the amount of sunlight that reaches the earth by scattering and absorbing the incoming radiation.

The MODIS fire and thermal anomalies products contain information unique to understanding the timing and distribution of fires and characteristics such as the energy emitted from the fire and is available for both day and night periods. Temporal composites include an eight-day and monthly day and night fire occurrence aggregation and a 
summary of the number of fires in classes related to the strength of the fire.

El-Askary et al (2008) have used aerosol product seasonally over Nile delta and Cairo, and they had found that the dust aerosols during MAM are found at higher altitudes, yet are low compared to the anthropogenic aerosols revealed from the CTP values shown in (figure.9a). The reason that they are found at higher altitudes as compared to SON aerosols is due to the normal temperature gradient during this particular time of the year over Cairo.

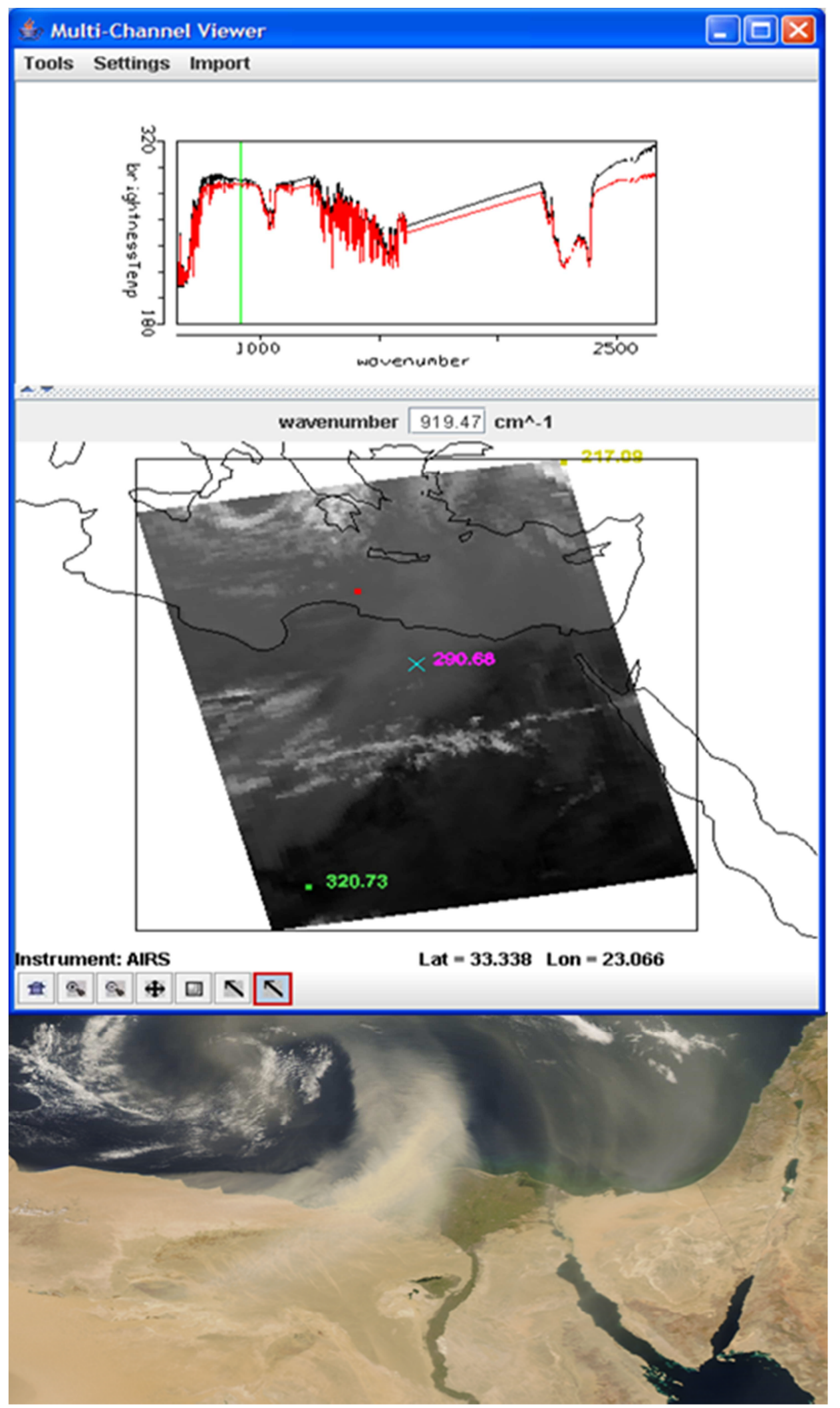

Figure 8. AIRS measurements over the same dust storm. 
However, the CTT during SON of the three years shows a decreasing trend from September to November, reflecting the higher levels of aerosols at the beginning and decreasing in concentration towards November, as shown in (Figure.9b). It is evident that, during the pollution episodes, lower CTTs were achieved due to the decreasing trend, as compared to the dust episodes that show an increasing trend in the CTT values (Devasthale et al. 2005). This implies that anthropogenic aerosols have an indirect impact in the thermal infrared,
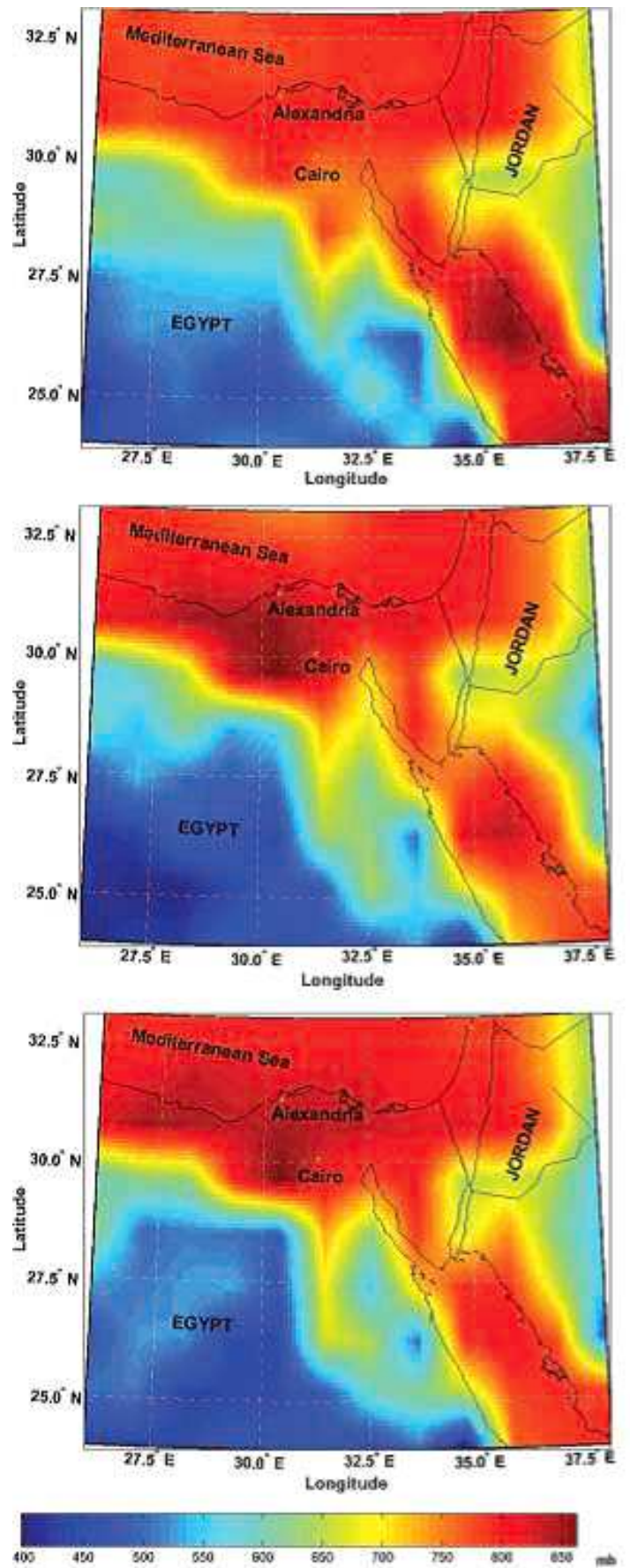

(a) compared to the dust aerosols. Anthropogenic pollutants during SON are found at a very low altitude, less than $1 \mathrm{~km}$ closer to the earth's surface, as revealed from the CTP values $(.920 \mathrm{mb})$. One important issue that needs to be addressed is whether MODIS aerosol retrievals (at $10 * 10 \mathrm{~km} 2$ grid size) are applicable to regional or local air pollution. Presented here are two case studies: (1) the Nile delta $\left(200 * 200 \mathrm{~km}^{2}\right)$, and (2) Greater Cairo $\left(40 * 50 \mathrm{~km}^{2}\right)$.
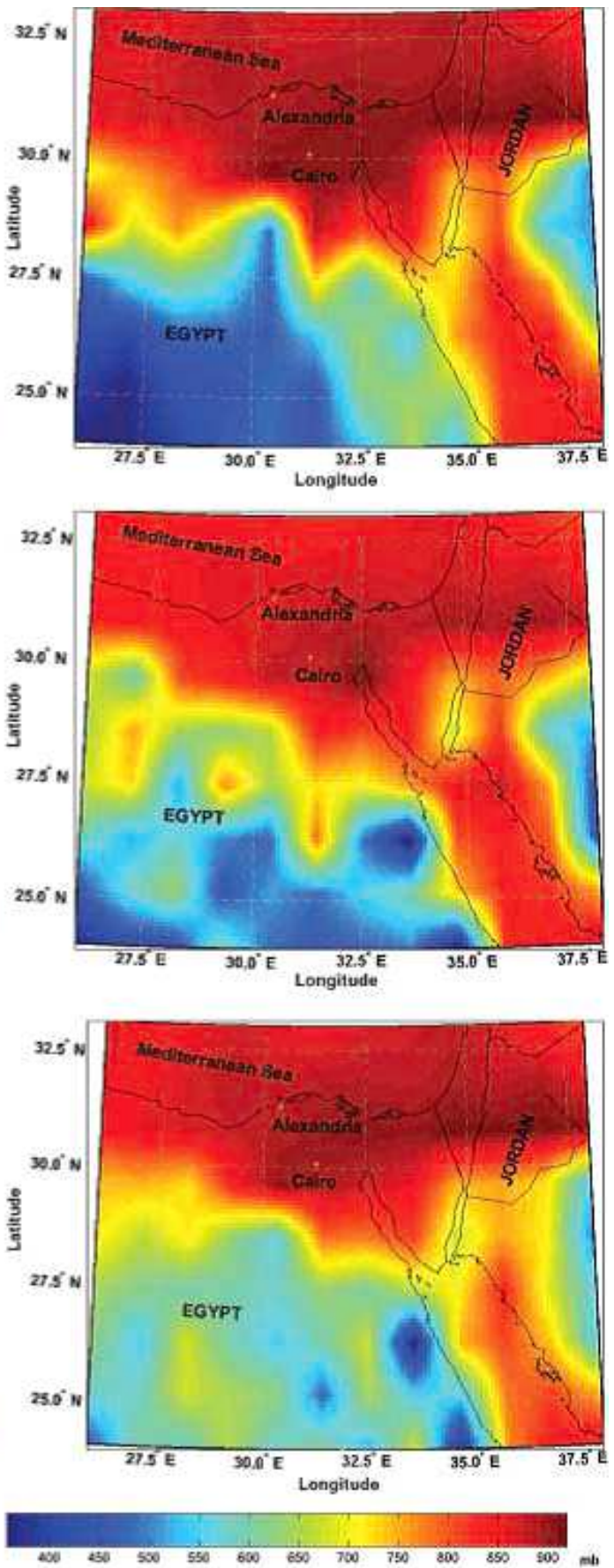

(b)

Figure 9. The cloud top pressure CTP over Cairo and the Greater Delta region during (a) spring (MAM) of 2004, 2005 and 2006, showing dust occurrence at higher altitudes, 750-800mb and (b) autumn (SON) of 2004, 2005 and 2006, showing anthropogenic aerosols occurrence at lower altitudes. $900 \mathrm{mb}$. (El-Askary et al, 2009). 


\section{Conclusion}

MODIS is ideal for monitoring large-scale changes in the biosphere that will yield new insights into the workings of the polluted area by the black cloud. While no current satellite sensor can directly measure that anthropic phenomenon concentrations in the atmosphere. MODIS from both the Terra and Aqua platforms can be successfully used as a climate model to integrate with climate data from stations for linear regression estimates and measure the change impacts of some elements such as daily maximum and minimum air temperatures changes, clouds cover, aerosols and carbon dioxide concentrations changes at a local scale on Nile Delta. MODIS products retrievals provide a useful perspective to the capability for monitoring regional and local air pollution and to identify the aerosol source as the burning of agricultural waste after harvest season in the Nile Delta region.

It was illustrated that the variability and similarity in the aerosol patterns over the entire region are associated with the presence of a clear annual component for the locations under investigation, this is in line with (El-Askary et al, 2009). The study has concluded that the Delta region is a strong source of
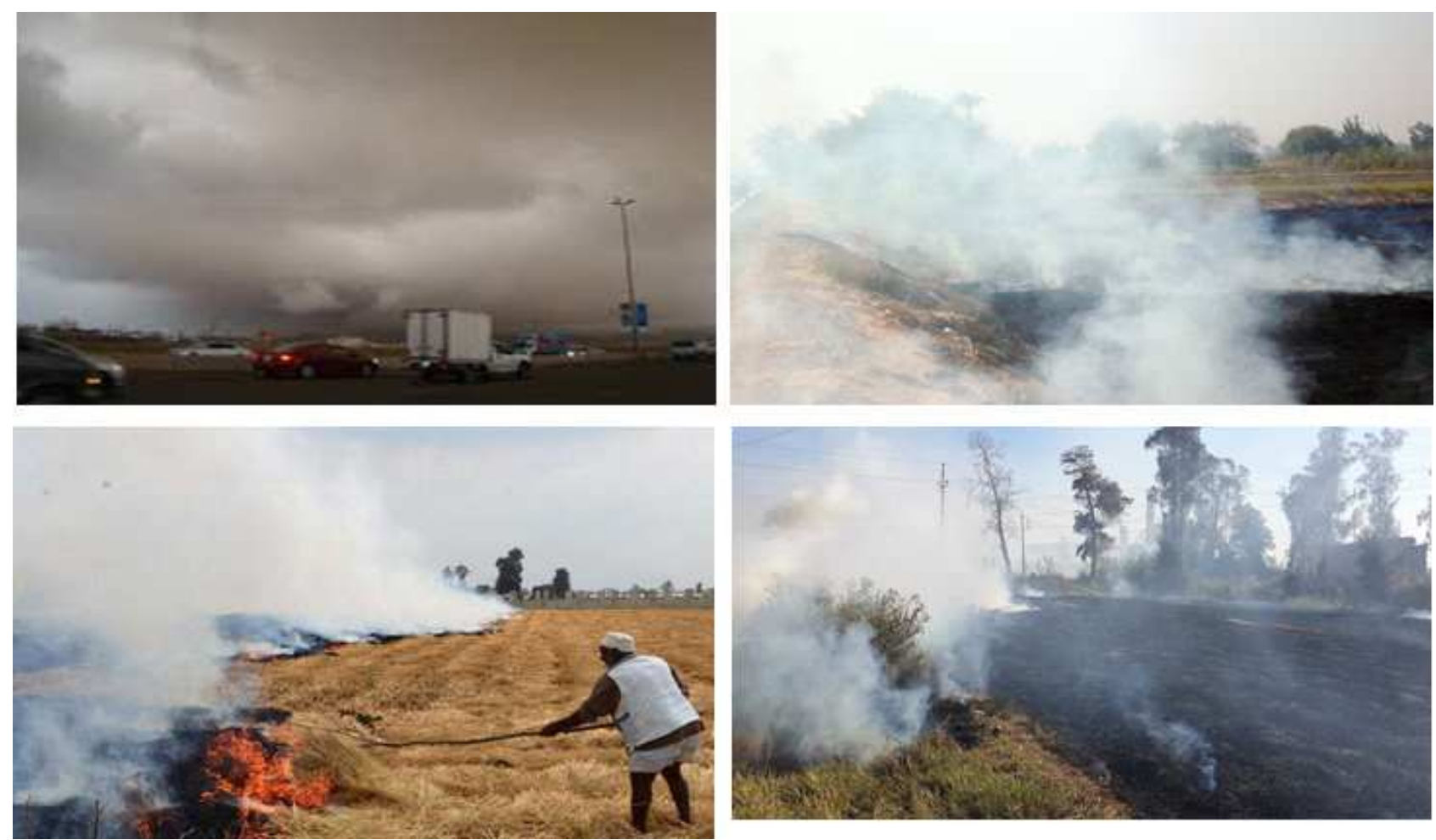
distances to other cities and neighboring Mediterranean countries and thus influence the aerosol radiative forcing at regional scales. Moreover, aerosols are likely to affect the water cycle by suppressing precipitation in a region of the world which is already very dry

AOD analysis clearly indicates large amounts of aerosols forming the black cloud events over various locations within the Delta region. The main reasons of the black cloud phenomena over Nile delta are the natural factors, such as desert dust and the anthropic factors, such as Biomass Burning especially for rice crop (Figure.10).

It should be noticed that aerosol from natural sources, such as sea salt and desert dust; contain larger particles than aerosols were emanating from human-produced combustion sources such as agricultural and deforestation burning or urban/industrial pollution. The mature MODIS algorithm includes aerosol optical thickness at several wavelengths, information on particle size, and aerosol-reflected flux at the top of the atmosphere, which is expected to be more accurate than the optical thickness retrievals.

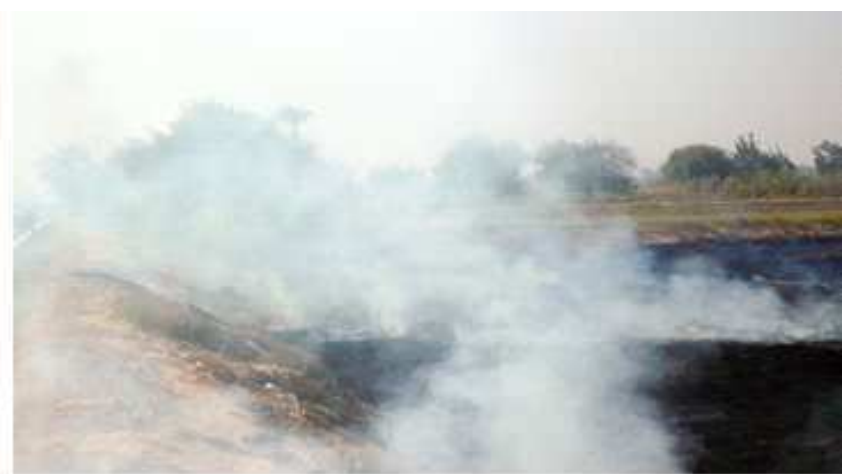

pollution airborne particles. These particles can travel long

Figure 10. The anthropic factors affecting black cloud over Nile delta.

\section{Acknowledgements}

This research was supported through training course organized by FORGEA international and Twas in Monteponi, Italy. The author would like to thank W. Paul Menzel, NOAA Satellite and Information Service University of Wisconsin, Madison, WI and Paolo Antonelli, UW/SSEC for their contributions to this work.

\section{References}

[1] Abu-Allaban, M.; Lowenthal, D.H.; Gertler, A.W. \& Labib, M. (2009). Sources of volatile organic compounds in Cairo's ambient air. Environmental Monitoring and Assessment, Vol.157, No.1-4, (October 2009), pp. 179-189, ISSN 0167-6369. 
[2] Alfaro, S.C. \& Abdel Wahab, M.M. (2006). Extreme variability of aerosol optical properties: The Cairo aerosol characterization experiment case study. Proceedings of the NATO Advanced Research Workshop on Remote Sensing of the Atmosphere for Environmental Security, pp. 285-299, ISBN: 978-1-4020-5089-3, Rabat, Morocco, 16-19 November, 2005.

[3] Astitha, M.; Kallos, G. \& Katsafados, P. (2008). Air pollution modeling in the Mediterranean Region: Analysis and forecasting of episodes. Atmospheric Research, Vol.89, No.4, (September 2008), pp. 358-364, ISSN 0169-8095

[4] B. H. Tang, Z.-L. Li, and Y. Y. Bi, "Estimation of land surface directional emissivity in midinfrared channel around $4.0 \mu \mathrm{m}$ from MODIS data," Opt. Express 17(5), 3173-3182 (2009), http://dx.doi.org/10.1364/OE.17.003173.

[5] Becker. F, and Z.-L. Li, "Towards a local split window method over land surfaces,” Int. J. Remote Sens. 11(3), 369-393 (1990), http://dx.doi.org/10.1080/01431169008955028.

[6] Barnaba, F. \& Gobbi, G.P. (2004). Aerosol seasonal variability over the Mediterranean region and relative impact of maritime, continental and Saharan dust particles over the basin from MODIS data in the year 2001. Atmospheric Chemistry and Physics Discussions, Vol.4, No.4, (August 2004), pp. 4285-4337, ISSN 16807367.

[7] Christopher D. G et al, 2006. The impacts of climate change in coastal marine systems. Ecology Letters, (2006) 9: 228-241.

[8] Dubovik, O., B. N. Holben, T. F. Eck, A. Smirnov, Y. J. Kaufman, M. D. King, D. Tanre', and I. Slutsker (2002), Variability of absorption and optical properties of key aerosol types observed in worldwide locations,J. Atmos. Sci., 59, 590608.

[9] El-Askary, H.; Farouk, R.; Ichoku, C. \& Kafatos, M. (2009). Transport of dust and anthropogenic aerosols across Alexandria, Egypt. Annales Geophysicae, Vol.27, No.7, (July 2009), pp. 2869-2879, ISSN 0992-7689

[10] El-Askary H. \& Kafatos, M. (2008). Dust Storm and Black Cloud Influence on Aerosol Optical Properties over Cairo and the Greater Delta Region, Egypt. International Journal of Remote Sensing, Vol.29, No.24, (December 2008), pp. 7199 7211, ISSN 0143-1161

[11] El-Askary, H. (2006). Air pollution Impact on Aerosol Variability over mega cities using Remote Sensing Technology: Case study, Cairo, Egypt. Egyptian Journal of Remote Sensing \& Space Science, Vol.9, (July 2006), pp. 31-40

[12] El-Askary, H.; Sarkar, S.; Kafatos, M. \& El-Ghazawi, T. (2003). A multisensor approach to dust storm monitoring over the Nile Delta. IEEE Transactions on Geoscience \& Remote Sensing, Vol.41, No.10, (October 2003), pp. 2386 - 2391, ISSN 0196-2892.

[13] El-Metwally, M.; Alfaro, S.C.; Abdel Wahab, M.M. \& Chatenet, B. (2008). Aerosol characteristics over urban Cairo: Seasonal variations as retrieved from Sun photometer measurements. Journal Geophysical. Research, Vol.113, No.D14219, (July 2008), pp. 1-13 ISSN 0148-0227.

[14] Jiménez-Muñoz. J, and J. A. Sobrino, "A generalized single-channel method for retrievingland surface temperature from remote sensing data," J. Geophys. Res. 108(D22), 46884697 (2003), http://dx.doi.org/10.1029/2003JD003480.

[15] Jiang. G-L. Li, and F. Nerry, "Land surface emissivity retrieval from combined mid-infrared and thermal infrared data of MSG-SEVIRI," Remote Sens. Environ. 105(4), 326-340 (2006), http://dx.doi.org/10.1016/j.rse.2006.07.015.

[16] Kaufman, Y. J., B. N. Holben, D. Tanre', I. Slutsker, A. Smirnov, and T. F. Eck (2000), Will aerosol measurements from Terra and Aqua polar orbiting satellites represent the daily aerosol abundance and properties, Geophys. Res. Lett., 27, $3861-3864$.

[17] Kaufman, Y. J., D. Tanre', and O. Boucher (2002), A satellite view of aerosols in the climate system, Nature, 419, 215-223.

[18] King, M. D., Y. J. Kaufman, W. P. Menzel, and D. Tanre, 1992: Remote Sensing of Cloud, Aerosol and Water Vapor Properties from the Moderate Resolution Imaging Spectrometer (MODIS). IEEE Trans. and Geoscience and Remote Sensing, 30, 2-27.

[19] King, M. D., W. P. Menzel, Y. J. Kaufman, D. Tanré, B. C. Gao, S. Platnick, S. A. Ackerman, L. Remer, R. Pincus, and P. A. Hubanks, 2003: Cloud and aerosol properties, precipitable water, and profiles of temperature and humidity from MODIS. IEEE Trans. Geosci. Remote Sens., 41, 442-458.

[20] King, M. D., W. P. Menzel, Y. J. Kaufman, D. Tanré, B. C. Gao, S. Platnick, S. A. Ackerman, L. A. Remer, R. Pincus, and P. A. Hubanks, 2003: Cloud, Aerosol and Water Vapor Properties from MODIS., IEEE Trans. Geosci. Remote Sens., 41, pp. $442-458$.

[21] Marey, H. S., Gille, J. C., El-Askary, H. M., Shalaby, E. A., and El- Raey, M. E.: Study of the formation of the "black cloud" and its dynamics over Cairo, Egypt, using MODIS and MISR sensors, J. Geophys. Res., 115, D21206, doi:10.1029/2010JD014384, 2010.

[22] Marey, H. S., El-Askary, H. M., Shalaby, E. A., and El- Raey, M. E: Aerosol climatology over Nile Delta based on MODIS, MISR and OMI satellite data, Atmos. Chem. Phys., 11, 1063710648, 2011.

[23] Menzel W. P., D. P. Wylie, and K. I. Strabala, 1992: Seasonal and diurnal changes in cirrus clouds as seen in four years of observations with the VAS, J. Appl. Meteor., 31, 370-385

[24] Menzel W. P. and J. F. W. Purdom, 1994: Introducing GOES-I: The first of a new generation of Geostationary Operational environmental Satellites. Bull. Amer. Meteor. Soc., Vol. 75, No. 5, pp. 757-78.

[25] Menzel W. P. et al, 2009: Laboratory Exercises for remote sensing applications with meteorological satellite, Space Science and Engineering Center, University of Wisconsin Madison, WI.

[26] Moeller, C. C., H. E. Revercomb, S. A. Ackerman, W. P. Menzel, and R. O. Knuteson, 2003: Evaluation of MODIS thermal IR band L1B radiances during SAFARI 2000. $J$. Geophys. Res., 108, D13, 8494.

[27] $\mathrm{Mu} \mathrm{Q}$, Heinsch FA, Zhao M, Running SW, Cleugh HA, Leuning R (2006b) Development of a global evapotranspiration algorithm based on MODIS and global meteorology data. Remote Sens Environ 111(4):519-536.

[28] Nerry. F: Petitcolin. F, and M. P. Stoll, "Bidirectional reflectivity in AVHRR channel 3: application to a region in North Africa," Remote Sens. Environ. 66(3), 298-316 (1998), http://dx.doi.org/10.1016/S0034-4257(98)00066-2. 
[29] Platnick S, M. D. King, S. A. Ackerman, W. P. Menzel, B. A. Baum, J. C. Riédi, R. A. Frey, 2003: The MODIS cloud products: algorithms and examples from Terra. IEEE Trans. Geosci. Remote Sens., 41, pp. 459-473.

[30] Qin. Z, A. Karnieli, and A. Berliner, "A mono-window algorithm for retrieving land surface temperature from landsat TM and its application to the Israel-Egypt border region," Int. J. Remote Sens. 22(18), 3719-3746 (2001), http://dx.doi.org/10.1080/01431160010006971.

[31] Remer, L. A., et al. (2005), The MODIS aerosol algorithm, products and validation, J. Atmos. Sci., in press.

[32] Sobrino. J, et al., "Multi-channel and multi-angle algorithms for estimating sea and land surface temperature with ATSR," Int. J. Remote Sens. 17(11), 2089-2114 (1996), http://dx. doi.org/10.1080/01431169608948760.

[33] Smirnov, A., B. N. Holben, T. F. Eck, O. Dubovik, and I. Slutsker (2000), Cloud screening and quality control algorithms for the AERONET data base, Remote Sens. Environ., 73, 337-349.
[34] Tang. T, et al., "Generalized split-window algorithm for estimate of land surface temperature from Chinese geostationary FengYun meteorological satellite (FY-2C) data," Sensors 8(2), 933-951 (2008), http://dx.doi.org/10.3390/s8020933.

[35] Zakey, A.S.; Abdel-Wahab, M.M.; Pettersson, J.B.C.; Gatari, M.J. \& Hallquist, M. (2008). Seasonal and spatial variation of atmospheric particulate matter in a developing megacity, the Greater Cairo, Egypt. Atmsfera Vol.21, No.2, (January 2008), pp. 171- 189, ISSN 0187-6236

[36] Zhang. H, "A physically based algorithm for land surface emissivity retrieval from combined mid-infrared and thermal infrared data," Sci. China Ser. E 43(Suppl 1), 22-33 (2000), http://dx.doi.org/10.1007/BF02916575.

[37] Z.-L. Li et al., "Evaluation of six methods for extracting relative emissivity spectra from thermal infrared images," Remote Sens. Environ. 69(3), 197-214 (1999), http://dx.doi.org/10.1016/S0034-4257 (99)00049-8. 